ANASTAS ANGJELI

anastasanjeli@gmail.com

ORCID ID: 0000-0003-4339-5172

REDION LULI

redion.luli@umsh.edu.al

ORCID ID: 0000-0002-6608-023X

Mediterranean University of Albania,

\title{
ARTIFICIAL INTELLIGENCE: THE RISK OF INVASION OF HUMAN RIGHTS AND LEGAL REGULATION OF THESE PROCESSES IN THE EU AND THE WORLD
}

\begin{abstract}
This paper analyzes the dangers faced by man and modern society in the light of the development of artificial intelligence and robotics in the fourth industrial revolution. The author examines the areas of human rights that are threatened by these advances in science and technology in case they are not properly monitored and regulated through legal advances. The historical and regional aspects of legislative regulation of the use of artificial intelligence units and robotics are investigated. Prospects of collision of artificial intelligence units with interests of the person and mankind, and also possible legal mechanisms of the resolution of the conflicts arising between them are analyzed. Using the methodology of comparative law, integration law, international law, analysis and synthesis, the author considers the latest documents of the European Union, EU member States, the United States, Russia, China, South Korea and other most representative countries of the world aimed at effective legal regulation of this promising area of development of modern law. The paper provides an analysis of the main trends in the evolution of modern law of science and technology that affect the life and realization of human and civil rights at the national, supranational and international level and the peculiarities of their legal regulation. The research is carried out on the interdisciplinary combination of elements of comparative law, integration, international and national law with reference to philosophy, sociology, history and
\end{abstract}


prognostics. While recognising the good work carried out in the AI law space, and acknowledging this area needs constant evaluation and agility in approach, this article advances the discussion, which is important given the gravity of the impacts of AI technologies, particularly on vulnerable individuals and groups, and their human rights.

KEYwORDS: artificial intelligence, robotics, EU law, domestic law of states, international law, human rights, legal regulation.

Human rights have always been the most convenient mechanism for managing people's behavior and an effective means of state influence on society. This is also true for integration organizations, in particular for their recognized model-the European Union. Moreover, they were raised to a new, supranational level and entered into an interesting interaction with both the national law of states and international law.

If the entire set of human and civil rights and freedoms was not defined at the time of the creation of the EU, or rather the ECSC, then it was immanently present in the communitarian idea Monnet-Schumann $1950^{1}$, in that states are united on the basis of the inalienable interests of the states and peoples constituting the union, which consist of citizens, and, consequently, of the interests of people too. In turn, integration should be carried out in stagesand at each stage there should be an improvement in the situation of citizens. These are the two main conditions for any integration.

At the same time, the very granting of rights to citizens began not with the legislative for fixing them in the constituent treaties, but with the practical activities of the Court of European communities. At first, these were the rights typical of the philosophy of the welfare state, and then they began to expand and received in the Charter of the European Union about

basic rights 2000 the most modern and attractive list ${ }^{2}$, which can be viewed as a kind of legal ideological showcase for European democracy. By the way, ideology is one of the most important integration tools not only within the framework of national states, but also in integration unions, where it rises to the supranational level.

1 Кашкин, С. Ю.,(2013). Четвериков А. О. Право Европейского Союза : учебник для бакалавров : в 2 т. / под ред. С. Ю. Кашкина. 4-е изд., перераб. и доп. М. : Юрайт. Т. 1 : Общая часть. Р. 66-68.

2 Charter of Fundamental Rights of the European Union 2012/c 326/02. // https://eur-lex. europa.eu/legal-content/EN/TXT/?uri=celex\%3A12012P\%2FTXT (last time accessed on 08.06.2021). 
With the collapse of the USSR, many social rights and socialist achievements were successfully borrowed by European law and practice, and the ideological struggle over the issue of rights and freedoms was completed in favor of Western democracy.

Today, under the conditions of the sixth scientific and technological order, an all-encompassing cardinal change of the world order is taking place, in which economics, politics, law, ideology, social relations and values are changing. Even the object of influence of ideology in modern conditions-the human personality on an individual basis and society of people in the collective sense-is under the influence of artificial intelligence and robotics and change dramatically and unpredictably.

Opportunities for the effective application of artificial intelligence and robotics make the amount of human material required to meet the needs of new economy, redundant. Therefore, it is not surprising that Professor Fukuyama recently highlighted the declining interest in democracy and the bureaucratization of domestic life as a trend in the development of modern society ${ }^{3}$.The struggle for the rights of numerous sexual and other minorities replaces concern for human rights and democracy today, while simultaneously contributing to the reduction of the "unnecessary" population. The strengthening of authoritarianism in a multipolar world, as well as discontent and aggression towards the West, call into question the model of globalization of human rights, dreamed about at the turn of the century.

On the way to the future, the world faces a choice: whose interests should be fundamental? State, society or individual? Traditional "statists" naturally consider the main actor of the future the state and its interests.

Communists in the near future see the direction of the new "controlled market economy" on the growth of social well-being, i.e. society and its interests as the main value.

Researchers of artificial intelligence and legislation in this area confidently put in the first place the human person, personality, his consciousness, individuality and security, including from artificial intelligence and robotics. I am a proponent of accounting primacy interests of the human person in

3 Fukuyama, F. (2020). The Pandemic and Political Order: It Takes a State. July/August. // URL: https://www.foreignaffairs.com/articles/world/2020-06-09/pandemic-and-political-order (date of access: 08.06.2021). 
development of human rights, for only by preserving the human personality, we can create a decent society; a fair state with a "human face" is called upon to integrate and unite the interests of man and society in the future.

How artificial intelligence and robotics affect the rights and freedoms of citizens?

First of all, this is the positive effect of such innovations, which is logical, predictable and understandable. We will not dwell on this in detail. But, the dangers and legal problems that are fraught with their application, as well as ways to protect human interests deserve a more detailed analysis.

Thus, the military use of artificial intelligence violates the most basic natural and inalienable human right-the right to life.

The use of artificial intelligence units in public administration undermines the idea of managing people by people based on democratic procedures and principles.

Application based on artificial intelligence of social ratings already used in China, completely rejects the principle of equality of citizens, returns society to the caste past, leads to governance based on fear and violence of the state over the powerless digitized person.

Artificial intelligence units can be successfully used in the process of judicial activity, including for the analysis of judicial practice and substantiation of judicial solutions. This can simultaneously lead to a violation of citizens' right to a fair trial. The acceleration of the consideration of court cases in this case does not always lead to the humanization of judicial activity and the observance of the principle of justice.

But this is one of the foundations of the modern concept of the rule of law, enshrined in most modern constitutions of the countries of the world, and follows from the essence of the primary documents of the European Union, which elevate these principles to a supranational level!

The possibility of robotization and the comprehensive application of artificial intelligence in production calls into question the very human right to work and the use of its results. Here the existence of the entire complex of labor law is under attack, first in the field of physical labor, and then mental.

The use of artificial technology intelligence allows you to openly intervene into private life, negating this right recently fought by people.

Collection of data about individuals and other personal information also allows the manipulation of human rights. 
Using artificial intelligence creates significant problems in the legal regulation of issues of ownership of intellectual property. And this is in conditions when services become more expensive than goods, and the material value of the results of intellectual and scientific activity exceeds the cost of services, not to mention the fact that they predetermine the prospects for the development of mankind. It is they who become the main values of the world of the future.

In light of the development of artificial intelligence and robotics reasonably the problem of recognizing the "electronic person" has arisen. Hence, the question of the legal personality of artificial intelligence units, as in human society, is divided into two groups:

- legal personality of units of artificial intelligence, comparable to the legal personality of an individual;

- legal personality of units of artificial intelligence, comparable to the legal personality of a legal entity.

The fragile human personality, its consciousness, emotional and sensory perception, which are still inaccessible to machines, is of great importance. These fundamental human qualities are also threatened by artificial intelligence. Thus, implantation of chips into a person, allowing him to regulate his behavior, can practically turn him into a robot and provide control of his behavior. Therefore, the most important issue is the preservation of the human personality, its sovereignty, truly human qualities and respect for its dignity.

The concept of an electronic person and comparing it with a person's personality allows us to speak about another similar phenomenon closely related to the human person - about "digital (electronic) personality" 4 . This includes a number of interrelated components of such a "personality".

First of all, it is digital identification of a person, already taking place in practice almost everywhere in the world. It allows you to collect and store all political, financial and economic, business, family-confidential, social-communicative, medical and any other information that characterizes a person and that can affect his behavior.

After all, this is nothing more than the "digital sovereignty of a person", which predetermines his entire existence, not only in the digital, but also in the real world.

4 Морхат, П. М.(2018). Право и искусственный интеллект / под ред. И. В. Понкина. М. : ЮнитиДана. Р. 306-401. 
This is the beginning of "digital life" (the beginning of the collection of electronic data about a person) and the "digital death" of the "digital personality" - (closing the corresponding files).

The parameters of this life are predetermined by "digital rights", which can already be regulated to one degree or another by legislation, and "digital obligations". Latest as newest show legal acts of Russia can also be ensured by punitive actions of the state, including real criminal prosecution.

The "hardware of digital personality" has already been fully developed, i.e. electronic tools and mechanisms to digitize the phenomena of the surrounding world.

The "digital personality software" is actively being created, which is an electronic program of artificial intelligence that allows the development of algorithms for managing the behavior of people, which form the basis of the object code of this phenomenon.

"Digital software" is pumped (by the owner or the state) with the help of "digital hardware" into the "digital personality" to control the "natural human personality", but the latter is not completely passive. It can either counteract this process to the best of its abilities, and engage in self-development and self-improvement and the formation or selection of its own "software". Thus, the real "digital software" of the "natural human personality" will be formed from two sources-external and internal.

The connection of the "digital personality" with the natural human personality has already begun in practice, but the possibilities of combining them, taking into account the prospects for the development of genetic engineering, require thoughtful preventive legal measures, since the future generation will live by different rules that need to be developed today.

How to determine at the legislative level the border between the permissible "humanization" of artificial intelligence and the "machinization" of the human being?

How to compare artificial intelligence and the natural intelligence of a human being, and how to consider the probable competition between them? Is legal regulation possible in this area and what should it be?

The creation of humanoid robots with artificial intelligence to serve people at home and provide various, including intimate services, in turn, can undermine the foundations of the human psyche, family ties and traditional relationships between men and women. Accordingly, this can lead to changes 
in the institution of the family and to the degradation of traditional family relations, reflecting these processes in the family law. This, in turn, affects the formation and development of the human personality, including its gender self-identification, with difficult predictable socio-legal and moral-psychological consequences.

A person's personality is formed in the process of upbringing and education, which is also intensively invaded by artificial intelligence in the form of a robot teacher. But no less a personality can be deformed in the process of "human" training aimed at training non-thinking service personnel (with a different set of competencies in terms of volume and functionality).

This is precisely the "competence-based" approach to education, which turns a person into a mechanical executor of specific functions, limiting creative, non-standard, a critical, constructive and unconventional approach, which is required by constantly changing living conditions. This contradicts the needs of the modern world, which consist not so much of concrete, easily formed and assessed hard skills, as in soft skills-talent, creative, extraordinary work, original solutions. This is what the competence-based approach does not teach.

Training of "obedient" but ineffective personnel and voters, including those with higher education, is carried out by teaching the choice of ready-made solutions in the process of tests, instead of teaching the analysis and synthesis of a changing environment, the ability to adequately react to these changes.

This kind of training forms standardized, "clip" thinking that does not meet the needs of the time, and it also creates conditions for the destruction of a creative personality, its deformation when faced with a fast self-learning artificial intelligence. In this issue, not so much a purely legal as an educational component is of greater importance.

Study of legal regulation of artificial intelligence and robotics started in the 1970s. in USA. There acted more than 100 university educational programs that included training courses in artificial intelligence ${ }^{5}$. Then, in the 1990s, interest in this area spread to a number of other foreign countries. Then the first regulatory documents were adopted to regulate the use of artificial intelligence. Since 2015, the issue of artificial

5 Hunt, E. (1978). Artificial Intelligence. P. 11. 
intelligence $(\mathrm{AI})$ and robotics has become a recognized problem in most countries of the world and in integration associations, going out to the supranational level.

Today, in general, it can be noted that most of the documents in the field of $\mathrm{AI}$ and robotics are recommendations, all kinds of declarations, charters, etc., which are not mandatory, binding. Let's take a look at some of them.

The Institute of Electrical and Electronic Engineers (IEEE) has developed three new ethical standards for artificial intelligence:

1. A standard for the ethical influence of robotic and intelligent systems that considers the actions of AI, explicitly or indirectly affecting behavior and emotions person.

2. Fault tolerance standard to create effective security measures to reduce the risk of errors and to safely terminate exploitation of compromised systems.

3. The standard of the influence of AI on the well-being of society, which should take into account how the produced artificial intelligence devices will change the well-being of people, will ensure the growth of labor productivity and economic growth. This is intended to provide a basis for data consistency between different experts ${ }^{6}$.

In 2018, the German Minister of Transport presented the report "Code of Ethics for Robo-Vehicles in Germany"7, which contained 20 recommendations for automakers of robotic vehicles ${ }^{8}$.

Ethical standards for $\mathrm{AI}^{9}$ developers have been developed and proposed by the Japan Society for Artificial Intelligence (JSAI). They should form the basis of activities in the creation of AI. These ethical guidelines should serve as a moral basis for JSAI members to better understand their responsibility to

6 Three new IEEE standards for making autonomous and intelligent systems safer // URL: https://site.ieee.org/sb-uol/three-new-ieee-standards-for-making-autonomous-and-intelligent-systems-safer/ (Date of access: 07.06.2021).

7 Ethics Commission Automated and Connected Driving // Federal Ministry of Transport and Digital Infrastructure. URL: https://www.bmvi.de/SharedDocs/EN/Documents/G/ ethic-commission-report.pdf?__ blob=publicationFile (Date of access: 05.06.2021).

8 Report on Automated and Connected Driving // Federal Ministry of Transport and Digital Infrastructure. URL: http://www.bmvi.de/SharedDocs/DE/Pressemitteilungen/2017/128dobrindt-massnahmenplan ethikregeln-fahrcomputer.html (Date of access: 06.06.2021).

9 The Japanese Society for Artificial Intelligence Ethical Guidelines // The Japanese Society for Artificial Intelligence (JSAI). URL: http://ai-elsi.org/wp-content/uploads/2017/05/JSAIEthical-Guidelines-1.pdf (Date of access: 03.06.2021). 
society. These include principles such as humanity, legality, respect for private life, honesty, security, transparency, responsibility to society, etc.

The Korea Robot Ethics Charter is a 7-article document. They enshrine the following ethical standards for robots and humans (sample text): striving for shared prosperity of man and machine, maintaining the dignity of each other, creating robots according to the best models, the robot-partner does not harm the person, and the man takes care of the robot, while the government is called upon to control compliance with these rules ${ }^{10}$.

The Asilomar principles of artificial intelligence were developed and adopted as a result of the conference of developers and researchers in the field of AI, held in 2017 in Asilomar (USA). These principles fix the humane goals, values and perspectives of creation, use and research of AI phenomena, their connection with science, culture, production, refusal to use them in activities hostile to humanity.

In the US, unlike the EU, there is no systemic legal regulation of $\mathrm{AI}$ and robotics, but there are serious legal acts in certain areas (for example, in the field of automated vehicles) and interesting programs for the development of robotics. At the same time, controversial issues are successfully resolved there through the use of case law ${ }^{11}$. There are no official strategies in the legal regulation of the use of artificial intelligence. It evokes well-founded criticism of the expert community ${ }^{12}$.

China is one of the most active participants in the regulation of AI. It possesses a complex system of acts aimed at the development of robotics and artificial intelligence technologies. First of all, this is the 13th Five-Year Development Plan (2016-2020) ${ }^{13}$. The next act is the Development Plan of

10 Legal Regulation of Autonomous Systems in South Korea on the Example of Robot Legislation / Prof. Dr. Dr. Eric Hilgendorf Minkyu Kim // URL: https://www.jura.uni (Date of access: 07.06.2021).

11 Calo R. Robotsin. American Law // Social Science Research Network. URL: https://papers. ssrn. com/sol3/papers.cfm?abstract_id=2737598 (Date of access: 29.05.2021).

12 Here's how the US needs to prepare for the age of artificial intelligence (April 2018) // Technology Review. URL: https://www.technologyreview.com/s/610379/heres-how-the-us-needs-to-prepare-for-the-age-of artificial-intelligence/ (Date of access: 20.05.2021).

13 The 13th Five-Year Plan For Economic and Social Development of the People's Republic of China (2016- 2020), 2016 // National Development and Reform Commission (NDRC) People's Republic of China. URL: http:// en.ndrc.gov.cn/newsrelease/201612/ P020161207645765233498.pdf (дата обращения: 01.06.2021). 
artificial intelligence technology of a new generation $(2017)^{14}$. China for the first time officially announced that the future belongs to artificial intelligence technologies, and China intends to become a world leader in this area.

According to the global government development program "Made in China$2025^{\prime 15}$, China should become a leader in the robotics and AI market in 2030.

In Russia, these issues are still at the very initial stage of study and regulation $^{16}$, and therefore are of particular importance and require a thorough, systematic and comprehensive study.

One of the most developed areas of legal regulation of robotics and artificial intelligence has been developed by the European Union. The Common Digital Single Market Strategy for Europe was approved by the European Council in $2015^{17}$ and is included to the list of 10 priority areas of activity of the European Commission $^{18}$. It includes questions of artificial intelligence and robotics.

On April 10, 201825 EU Member States signed the Declaration on Cooperation in the Field of Artificial Intelligence. It addresses the issues of increasing the technological and production potential of Europe in the field of AI and its application to solve such socio-economic problems as labor market transformation and modernization of education systems in Europe, including continuing education and retraining of EU citizens; ensuring that legal and ethical standards are consistent with the goals and values of the Union, including the inviolability of private life, personal data protection, and principles such as transparency, proportionality, accountability, etc.

An important real step towards creating a common artificial intelligence platform for a united Europe was the Artificial Intelligence Project of January 1, 201919,

14 План развития технологий искусственного интеллекта нового поколения 2017 // Официальный Портал правительства KHP. URL: http://www.gov.cn/zhengce/content/2017-07/20/content_5211996.htm (Date of access: 29.05.2021).

15 China Innovation Project: A Guide to Understanding China's Next Wave of Innovation// URL: https://projects.iq.harvard.edu/innovation/made-china-2025-explained (Date of access: 04.06.2021).

16 Морхат П. М. Право и искусственный интеллект. Р. 10, 20.

17 Communication from the Commission COM(2015) 192 «A Digital Single Market Strategy for Europe». URL: https:// ec.europa.eu. (Date of access: 25.05.2021).

18 Juncker J.-C. A New Start for Europe: My Agenda for Jobs, Growth, Fairness and Democratic Change. Political Guidelines for the next European Commission. Strasbourg, 15 July 2014.

URL: https://www.eesc.europa.eu/resources/docs/jean-claude-juncker--political-guidelines. pdf. (Date of access: 07.06.2021).

19 The Ai4eu Platform. URL: https://www.ai4eu.eu/ai4eu-platform (Date of access: 05.06.2021). 
which concentrated in itself the main achievements and investments in this area. Robotics and artificial intelligence have become one of the most famous technological trends of our century ${ }^{20}$ and one of the real innovation challenges of today ${ }^{21}$. Already today, artificial intelligence units are being developed, functioning and actively used. Global revenue from cognitive systems and artificial intelligence is projected to grow from $\$ 8$ billion in 2016 to over $\$ 47$ billion in $2021^{22}$.

An analysis of the latest domestic legal initiatives and solutions shows that many of the problems generated by the development of artificial intelligence in USA, Russia, the Eurasian Union, the European Union and in the world as a whole are of the same type and can and should be solved by joint efforts, and therefore it is logical to borrow the experience and achievements from each other.

In order to protect a person from the negative impact of artificial intelligence, is required the legal control over the creators, manufacturers, owners, users, tenants of artificial intelligence units, causing damage to people and property, as well as legal control over those individuals and organizations that cause illegal damage to artificial intelligence units.

Goods and possible evil emanating from artificial intelligence units must be under clear and strict legal control of a person, their actions must be combined with responsibility, accountability, and, where appropriate, with immediate discontinuity.

Therefore, mankind moving forward should adequately imagine the possible paths, rates and consequences of this movement and be able to stop in time. Hence, a paradoxical thought arises about the necessity and possibility of legal regulation of the human instinct for self-preservation, about the collective self-preservation of human society in a possible collision with artificial intelligence and about the inadmissibility of the uncontrolled appearance and self-development of this instinct in an intelligent robot!

The fundamental problem of the possibility and necessity of the formation and consistent improvement of the self-preservation instinct of mankind as

20 Draft Report with recommendations to the Commission on Civil Law Rules on Robotics - 22 p. - P. 20. URL: https://www.europarl.europa.eu/doceo/document/A-8-2017-0005_ EN.html. (Date of access: 06.06.2021).

21 See: Морхат П. М. Понятие инноваций в науке : Обзор научной мысли : науч. монография / Институт гос.-конф. отношений и права. - М. : Буки Веди, 2015. - 94 с.

22 Firth-Butterfield, K., Chae, Y., Allgrove, B., Kitsara I. (2018). Artificial Intelligence Collides with Patent Law: White Paper / Center for the Fourth Industrial Revolution. Geneva (Switzerland) : World Economic Forum. 23 p. P. 5. 
a whole, inseparable from the self-preservation of the person himself and his personality, is today one of the main tasks of the entire complex of technical, humanitarian and social sciences.

At the same time, it should be noted that spirituality, morality and the instinct of self-preservation of mankind, as, in fact, of the person himself, which should change and develop as a natural reaction to changing living conditions and adaptation to them, change more slowly than the development of science and technology which are not quite predictable yet. This is one of the main controversy threatening the existence of human being and humanity.

It is in this promising vein that, in our opinion, the development of the thought of a researcher of legal science, both a theoretician and a legislator, and a practitioner, should go when searching for ways to optimally solve the development of relations between artificial intelligence, robotics, the digital world and the human community. 